\title{
Haplotype of RNASE 3 polymorphisms is associated with severe malaria in an Indian population
}

\author{
Benudhar Mukhi $^{1,3} \cdot$ Himanshu Gupta $^{2}(-) \cdot$ Samuel C. Wassmer $^{2} \cdot$ Anupkumar R. Anvikar $^{1} \cdot$ Susanta Kumar Ghosh $^{1,3}$
}

Received: 5 July 2020 / Accepted: 20 October 2020 / Published online: 28 October 2020

(c) Springer Nature B.V. 2020

\begin{abstract}
Severe malaria (SM) caused by Plasmodium falciparum (Pf) infection has been associated with life-threatening anemia, metabolic acidosis, cerebral malaria and multiorgan dysfunction. It may lead to death if not treated promptly. RNASE 3 has been linked to $P f$ growth inhibition and its polymorphisms found associated with SM and cerebral malaria in African populations. This study aimed to assess the association of RNASE 3 polymorphisms with SM in an Indian population. RNASE 3 gene and flanking regions were amplified followed by direct DNA sequencing in 151 Indian patients who visited Wenlock District Government Hospital, Mangalore, Karnataka, India. Allele, genotype and haplotype frequencies were compared between patients with SM $(n=47)$ and uncomplicated malaria $(U M ; n=104)$. Homozygous mutant genotype was only found for rs2233860 ( $+499 \mathrm{G}>\mathrm{C}$ ) polymorphism ( $<1 \%$ frequency). No significant genetic associations were found for RNASE 3 polymorphism genotypes and alleles in Indian SM patients using the Fisher's exact test. C-G-G haplotype of rs 2233859 $(-38 \mathrm{C}>\mathrm{A})$, rs $2073342(+371 \mathrm{C}>\mathrm{G})$ and $\mathrm{rs} 2233860(+499 \mathrm{G}>\mathrm{C})$ polymorphisms was correlated significantly with SM patients $(\mathrm{OR}=3.03 ; \mathrm{p}=0.008)$ after Bonferroni correction. A haplotype of RNASE 3 gene was found associated with an increased risk of SM and confirming that RNASE 3 gene plays a role in susceptibility to SM.
\end{abstract}

Keywords Severe malaria $\cdot$ RNASE $3 \cdot$ Polymorphisms $\cdot$ ECP $\cdot$ Plasmodium falciparum

\section{Introduction}

Malaria remains to be a major public health problem in low and middle-income countries, especially in the sub-Saharan region. The World Health Organization (WHO) estimated that 228 million cases of malaria and 405,000 related deaths occurred globally in 2018 [1]. 19 sub-Saharan African

Electronic supplementary material The online version of this article (https://doi.org/10.1007/s11033-020-05934-1) contains supplementary material, which is available to authorized users.

Himanshu Gupta

Himanshu.gupta@1shtm.ac.uk;

himanshugupta.hcu@gmail.com

1 ICMR-National Institute of Malaria Research, New Delhi, India

2 Department of Infection Biology, Faculty of Infectious and Tropical Diseases, London School of Hygiene and Tropical Medicine, Keppel St. Bloomsbury, London WC1E 7HT, UK

3 Manipal Academy of Higher Education, Manipal 576104, Karnataka, India countries and India were responsible for carrying approximately $85 \%$ of the worldwide burden [1]. Plasmodium falciparum $(P f)$ malaria is a complex disease with a wide spectrum of clinical manifestations ranging from uncomplicated (UM) to severe malaria (SM). SM is defined by life-threatening anemia, metabolic acidosis, cerebral malaria (CM), and multiorgan system involvement [2]. Sequestration of $P f$-parasitized erythrocytes within the microvasculature of vital organs in the human host is considered a key pathogenic event leading to SM [3, 4]. P. falciparum erythrocyte membrane protein 1 (PfEMP1) is encoded by the multicopy var gene family and mediates the sequestration of parasitized erythrocytes to host receptors [5, 6].

Both parasite and host factors have been identified as significant contributors to SM [3]. This includes parasite genes, and var groups A, B, as well as domain cassette (DC) 8, DC11 and DC13 have been shown to be associated with SM [7, 8]. Similarly, among host genes, polymorphisms in intercellular adhesion molecule 1 (ICAM-1), cluster of differentiation 36 (CD36), tumor necrosis factoralpha (TNF- $\alpha$ ), Interferon-gamma (IFN- $\gamma$ ), interleukin- $1 \beta$, complement receptor-1 (CR-1), ATP binding cassette 
subfamily $B$ member 1 (ABCB1) and adenosine A2a receptor (ADORA2A) have linked to the development of SM [9-16]. Ribonuclease 3 (RNASE 3), which encodes eosinophil cationic protein (ECP), an important protein produced by eosinophils during inflammation and infection [17, 18], was found to increase susceptibility to SM [19-22]. Indeed, SM patients had higher ECP levels and hypereosinophilia compared to UM patients [21]. In addition, another study demonstrated that ECP can suppress the growth of $P f$ in in vitro [22]. Above findings led to several genetic studies of the RNASE 3 gene in African populations [19, 20], which all showed an association between RNASE 3 polymorphisms $(+371 \mathrm{C}>\mathrm{G}$ and $+499 \mathrm{G}>\mathrm{C})$ and SM $[19,20]$, further confirming its role in severity of the disease. The minor allele frequencies of $+371 \mathrm{C}>\mathrm{G}$ and $+499 \mathrm{G}>\mathrm{C}$ polymorphisms were more than 0.20 in African populations [19, 20]. These RNASE 3 polymorphisms have also been associated with other disease susceptibility such as allergic asthma [23] and parasitic-helminth infection [24].

Here, we conducted a case-control study to assess the association of RNASE 3 polymorphisms with SM in India, as the same polymorphism can have heterogeneous effect in two populations due to genetic differences [25]. RNASE 3 polymorphism alleles, genotypes and haplotypes frequencies were compared between falciparum malaria patients with SM and UM.

\section{Materials and methods}

\section{Ethical statement}

All subjects were recruited from the Department of Medicine, Wenlock District Government Hospital, Mangalore, Karnataka, India. Prior written informed consent was obtained from each adult patient, or informed assent from a parent or legal guardian if the individual was $\leq 18$ years. The research and ethics committee of the Kasturba Medical College (KMC) under Manipal Academy of Higher Education, Mangalore, Karnataka, India, approved the study (IEC KMC MLR 03-16/49). The Institutional review board of ICMR-National Institute of Malaria Research, New Delhi, India also reviewed and approved the study (ECR/NIMR/ EC/2012/39). Patient data obtained in this study was kept confidential and unique laboratory code was used for laboratory and dataset analyses.

\section{Study design and population}

For this case-control study, we used a convenience sampling method, whereby all available malaria subjects in a specific area are included. We enrolled patients with SM and UM caused by P. falciparum who were admitted or visited to the Department of Medicine, Wenlock District Government Hospital, the largest health facility in Mangalore and the main malaria referral hospital in the region, Karnataka, India, from July 2015 to December 2018. UM patients were used as controls to understand the role of RNASE 3 polymorphisms in severe malaria. SM was defined based on the modified WHO criteria [26]. A total of 151 patients were recruited (age range: $1-75$ years), including $19(12.6 \%)$ children ( $\leq 18$ years, median: 12; interquartile range: 8$)$ and 132 (87.4\%) adults (>18, median: 32 ; interquartile range: 22 ) participants; 19 patients were female $(12.6 \%)$. All the participants were from the same Tuluva ethnic group, as determined on the basis of shared history, food habit, language and habitat region. Patients with axillary temperature $>37.5^{\circ} \mathrm{C}$ and confirmed mono-infection of $P f$ by expert microscopy and rapid diagnostic tests (RDTs) were included in the study. $P$. falciparum positive patients with other Plasmodium species, HIV, HBsAg, HCV, pneumonia, bacterial meningitis, sepsis and tuberculosis co-infections were excluded from the study.

\section{Parasite quantification and treatment}

Giemsa-stained thick and thin blood smears were air-dried, and tested for the presence of $P f$ parasites under a light microscope fitted with a $100 \times$ oil immersion lens and a $10 \times$ eyepiece (Zeiss Primo Star, Germany), and parasitemia was quantified as previously described [27]. In addition, the National Vector Borne Disease Control Programme (NVBDCP) approved RDT kits were used as per the manufacturer's instructions to confirm Plasmodium infections. These kits were FalciVax ${ }^{\mathrm{TM}}$ Rapid Test for Malaria Pv/Pf (Ref. No.: 50301002), Onsite Malaria Pf/Pv Ag Rapid Test (Ref. No.: R0112C) and SD Bioline Malaria Ag P.f/P.v (Ref. No.: 05FK80) targeting both $P$. vivax- specific $\mathrm{pLDH}$ and P. falciparum-specific HRP-2 antigens. All the cases were successfully treated with the artemisinin-based combination therapy (ACT) as prescribed by the National Vector Borne Control Programme.

\section{Laboratory procedures}

Patients positive for mono- $P f$ infections were subjected to venipuncture; $4 \mathrm{ml}$ of whole blood was collected in EDTA Vacutainers (BD Vacutainer ${ }^{\circledR}$ ) for hematological tests, and a further $4 \mathrm{ml}$ blood was taken for biochemical liver and kidney function tests using Clot Activator Vacutainers (BD Vacutainer $\left.{ }^{\circledR}\right)$. DxH 800 Hematology (Beckman Coulter) and Cobas ${ }^{\circledR} 6000$ (Roche) analyzers were used for hematological and biochemical tests, respectively. 


\section{Molecular procedures}

EDTA blood collected for each patient was sent to Chromous Biotech, Pvt. LTD, Bangalore, India (https://www. chromous.com/index.php?q=chromous-biotech/about-us), for DNA isolation, RNASE 3 gene amplification and DNA Sanger sequencing. In brief, 100-250 $\mu \mathrm{l}$ of blood was used for DNA isolation using the Chromous Biotech DNA extraction kit (Cat. No.: RKN25/26). Finally, DNA was eluted in $35 \mu 1$ of elution buffer available in the kit. RNASE 3 gene was amplified using two primer sets (Set-1: Fw: 5'-TCCAGC AAGAGTGGTGGATGAGAT-3' and Rv: 5'-CTGTTGTCA CATGCAACTACATAG-3'; Set-2: Fw: 5'-TTGCCATCC AGCACATCAGTCTGA and Rv: 5'-CTGGTTCCACCT CTATTACGATTGC-3') covering a 2047 bp region (chr14: 20890932-20892978, including upstream and downstream sequences) of the RNASE 3 gene and targeting more than 150 reported polymorphisms (as per the Ensembl release 101; Human GRCh38.p13). In brief, RNASE 3 gene fragments were amplified separately in $50 \mu \mathrm{l}$ reactions including $200 \mathrm{ng}$ of each forward and reverse primers of set- 1 and set- $2,5 \mu \mathrm{l}$ of $10 \times$ PCR buffer, $2 \mu \mathrm{l}$ of dNTPs $(10 \mathrm{mM}), 2 \mu \mathrm{l}$ of template DNA and 3 units of Taq ${ }^{\circledR}$ DNA polymerase, reaction volume was raised by PCR-grade water. The PCR reaction was performed with the initial denaturation at $94{ }^{\circ} \mathrm{C}$ for $5 \mathrm{~min}$, followed by 35 cycles of $94{ }^{\circ} \mathrm{C}$ for $30 \mathrm{~s}, 52{ }^{\circ} \mathrm{C}$ for $30 \mathrm{~s}, 72{ }^{\circ} \mathrm{C}$ for $2 \mathrm{~min}$, followed by final extension at $72{ }^{\circ} \mathrm{C}$ for $7 \mathrm{~min}$. DNA sequencing [28] was performed using an ABI Prism (Applied Biosystems, USA) 3500 genetic analyzer for automated DNA sequencer using ABI Prism BigDye Terminator v3.1 cycle sequencing kit. The direct DNA sequencing was performed for the two amplicons described above, of $1177 \mathrm{bp}$ and $1180 \mathrm{bp}$ long regions of RNASE 3 containing all the reported gene polymorphisms. The variations in the sequences were identified by sequence alignment using NCBI blast with reference sequence NC_000014.9.

\section{Statistical analysis}

To compare continuous data and categorical data between groups, respectively, we performed Mann Whitney U test and Fisher's exact test. Odds ratio (OR), 95\% confidence interval $(95 \% \mathrm{CI})$ and $\mathrm{p}$ value for the mutant allele of each RNASE 3 polymorphisms were calculated using an online version of MedCalc software (https://www.medcalc.org/ calc/odds_ratio.php). The SHEsis (https://analysis.bio-x. $\mathrm{cn} /$ SHEsisMain.htm), an online software tool, was used for haplotype and linkage disequilibrium (LD) analyses. The software uses a partition-ligation-combination-subdivision expectation maximization algorithm for haplotype inference with multiallelic markers for haplotype analysis. All haplotypes with a frequency below 0.03 were discarded $[29,30]$.
We defined statistical significance as $\mathrm{p}<0.05$. Bonferroni correction was applied for multiple comparisons.

\section{Results}

\section{Patients}

All study participants $(\mathrm{n}=151)$ were positive for $P$. falciparum mono-infection, and no other species including $P$. vivax, $P$. malariae, $P$. ovale or $P$. knowlesi were identified. Among participants, median $( \pm \mathrm{IQR})$ parasitemia was $39,446 \pm 52,106$ parasites/ $\mu \mathrm{L}$ and median ( \pm IQR) age was $27 \pm 21$ years. Thrombocytopenia $(<150,000$ platelets $/ \mu \mathrm{L})$ was found in $60.9 \%$ of patients (92/151), and $10.6 \%(16 / 151)$ had severe thrombocytopenia $(<50,000$ platelets $/ \mu \mathrm{L}) .31 .1 \%$ (47/151) and 68.9\% (104/151) of all patients were diagnosed with SM and UM, respectively. Comparisons between the demographic, hematological and biochemical laboratory findings of the participants with SM and UM was performed and are shown in Table 1. Statistically significant differences were only found for age, parasitemia, red blood cell counts, urea, bilirubin, AST, ALT, albumin levels and ratios of albumin and globulin (Table 1). Among patients with SM, $10.6 \%$ (5/47) and 23.4\% (11/47) of patients had multiple organ dysfunction and splenomegaly, respectively. Information on symptoms of severity of the patients as per the WHO criteria [26] is presented in Table 2.

\section{Genetic association analyses}

We successfully amplified 151 samples for the RNASE 3 gene followed by direct DNA sequencing, covering more than 150 polymorphisms. All the reported polymorphisms were present in the wild type form except for three polymorphisms [rs2233860 $(+499 \mathrm{G}>\mathrm{C}), \mathrm{rs} 2233859(-38 \mathrm{C}>\mathrm{A})$ and rs2073342 (+371C $>\mathrm{G})$ ], and no novel polymorphisms were identified in our samples. Among $+499 \mathrm{G}>\mathrm{C},-38 \mathrm{C}>\mathrm{A}$ and $+371 \mathrm{C}>\mathrm{G}$ polymorphisms (Fig. S1), a homozygous mutant genotype was only found for $+499 \mathrm{G}>\mathrm{C}$ polymorphism, only $0.7 \%$ (1/151) of patients possessed a mutant genotype (CC). However, $-38 \mathrm{C}>\mathrm{A}$ and $+371 \mathrm{C}>\mathrm{G}$ polymorphisms were either present in the form of homozygous wild-type or heterozygous genotypes in the studied participants. Thus, $-38 \mathrm{C}>\mathrm{A},+371 \mathrm{C}>\mathrm{G}$ and $+499 \mathrm{G}>\mathrm{C}$ were further considered for odds ratio, haplotype and linkage disequilibrium analyses. The minor allele and genotype frequencies of the entire studied population are shown in Table 3.

Odds ratio was calculated for different genetic models, neither alleles nor genotypes of $-38 \mathrm{C}>\mathrm{A},+371 \mathrm{C}>\mathrm{G}$ and $+499 \mathrm{G}>\mathrm{C}$ polymorphisms were found associated with SM and UM patients (Table 4). 
Table 1 Demographic, hematological and biochemical laboratory findings of patients at the time of admission, 2015-2018

\begin{tabular}{|c|c|c|c|}
\hline & $\operatorname{SM}(n=47)$ & $\mathrm{UM}(\mathrm{n}=104)$ & $\mathrm{p}$-value \\
\hline Female, no. $(\%)$ & $6(12.8)$ & $13(12.5)$ & 1.000 \\
\hline Age (year) & $36(26.0)$ & $26(20.0)$ & 0.007 \\
\hline Hemoglobin levels (g/dL) & $12.3(3.4)$ & $12.2(3.5)$ & 0.828 \\
\hline Total RBC counts (million $/ \mathrm{mm}^{3}$ ) & $4.48(1.1)$ & $4.92(1.1)$ & 0.049 \\
\hline Platelet counts (per $\mu \mathrm{L}$ ) & $121,000(107,000)$ & $112,000(65,750)$ & 0.419 \\
\hline Blood glucose $(\mathrm{mg} / \mathrm{dL})$ & $74(37)$ & $79(35.8)$ & 0.633 \\
\hline Blood urea $(\mathrm{mg} / \mathrm{dL})$ & $37.5(17.6)$ & $28.8(16.1)$ & 0.002 \\
\hline Serum creatinine $(\mathrm{mg} / \mathrm{dL})$ & $0.90(0.7)$ & $0.88(0.4)$ & 0.266 \\
\hline Serum bilirubin (mg/dL) & $2.7(2.8)$ & $1.6(1.2)$ & $<0.001$ \\
\hline AST levels (IU/L) & $68.0(61.5)$ & $56.7(60.9)$ & 0.021 \\
\hline ALT levels (IU/L) & $63.5(40.5)$ & $41.5(51.2)$ & 0.008 \\
\hline Alkaline phosphatase (IU/L) & $310.4(195.9)$ & $257.5(198.7)$ & 0.092 \\
\hline Total protein levels (g/dL) & $7.0(1.3)$ & $7.1(0.8)$ & 0.881 \\
\hline Albumin levels (g/dL) & $3.7(0.5)$ & $3.9(0.7)$ & 0.038 \\
\hline Globulin levels (g/dL) & $3.2(1.2)$ & $3.1(0.9)$ & 0.186 \\
\hline A:G Ratio & $1.1(0.4)$ & $1.2(0.5)$ & 0.002 \\
\hline Parasitemia (per $\mu \mathrm{L})$ & $76,357(104,280)$ & $28,735(40,816)$ & $<0.001$ \\
\hline
\end{tabular}

For continuous variables, values are expressed in median and interquartile range in bracket

$S M$ Severe malaria; $U M$ Uncomplicated malaria; $A: G$ Albumin:globulin ratio
Table 2 Severe malaria symptoms according to WHO criteria in patients enrolled in the study

\begin{tabular}{lc}
\hline Severe malaria symptoms & Patients, $\mathrm{n}(\%)$ \\
\hline Metabolic acidosis & $30(63.8)$ \\
Jaundice & $9(19.1)$ \\
Hypoglycemia & $1(2.1)$ \\
Severe anemia & $1(2.1)$ \\
Acute kidney injury & $1(2.1)$ \\
Pulmonary edema & $18(38.3)$ \\
Multiple convulsions & $3(6.4)$ \\
Hyperparasitemia & $1(2.1)$ \\
\hline
\end{tabular}

The haplotype analysis was performed for three $(-38 \mathrm{C}>\mathrm{A},+371 \mathrm{C}>\mathrm{G}$ and $+499 \mathrm{G}>\mathrm{C})$ polymorphisms of RNASE 3 gene by using SHEsis. Among the 8 possible haplotypes comprising the three polymorphic loci, C-G-G haplotype was associated with $\mathrm{SM}$ patients $(\mathrm{OR}=3.03$; $\mathrm{p}=0.008)$ after Bonferroni correction. No, haplotypes were found associated with UM. The results of the haplotype analysis are shown in Table 5 .

LD was estimated for the three polymorphisms using the $\mathrm{D}^{\prime}$ values. The analysis showed strong linkage disequilibrium $\left(\mathrm{D}^{\prime}=1\right.$ or $\left.>0.75\right)$ between $\operatorname{rs} 2233859(-38 \mathrm{C}>\mathrm{A})$, rs2073342 (+371C $>$ G) and rs2233860 $(+499 \mathrm{G}>\mathrm{C})$ polymorphisms in UM patients. However, no complete linkage
Table 3 Genotype frequencies of studied polymorphisms in the Indian population

\begin{tabular}{|c|c|c|c|c|c|c|c|}
\hline rsIDs & Location & Amino acid & $\begin{array}{l}\text { Wild } \\
\text { Geno }\end{array}$ & $\begin{array}{l}\text { Heterozygous } \\
\text { ype frequency }\end{array}$ & Mutant & MAF $^{\#}$ & $\begin{array}{l}\text { Asia } \\
\text { MAF } \\
(\text { dbSNP) }\end{array}$ \\
\hline $\begin{array}{l}\mathrm{rs} 2233859 \\
(-38 \mathrm{C}>\mathrm{A})\end{array}$ & $\begin{array}{l}\text { Intron } \\
* \text { chr14:20,891,649 }\end{array}$ & & 42.4 & 57.6 & 0 & A $(0.288)$ & 0.312 \\
\hline $\begin{array}{l}\text { rs2073342 } \\
(+371 C>G)\end{array}$ & $\begin{array}{l}\text { Exon2 } \\
\text { *chr14:20,892,057 }\end{array}$ & $\mathrm{T} / \mathrm{R}$ & 20.5 & 79.5 & 0 & $\mathrm{G}(0.397)$ & 0.73 \\
\hline $\begin{array}{l}\text { rs2233860 } \\
(+499 \mathrm{G}>\mathrm{C})\end{array}$ & $\begin{array}{l}\text { 3'UTR } \\
\text { *chr14:20,892,185 }\end{array}$ & & 83.4 & 15.9 & 0.7 & $\mathrm{C}(0.086)$ & 0.1 \\
\hline
\end{tabular}

$M A F$ minor allele frequency

*GRCh38.p12

\#Present study data 
Table 4 Odds ratio analysis of RNASE 3 polymorphisms in severe and uncomplicated malaria patients

\begin{tabular}{|c|c|c|c|c|c|}
\hline rsIDs & Genotypes/alleles & $\mathrm{SM}(\mathrm{n}=47)$ & $\mathrm{UM}(\mathrm{n}=104)$ & Models & OR (95\%CI), p-value \\
\hline \multirow{8}{*}{$\begin{array}{l}\text { rs } 2233859 \\
(-38 \mathrm{C}>\mathrm{A})\end{array}$} & $\mathrm{CC}$ & 23 & 41 & & \\
\hline & $\mathrm{CA}$ & 24 & 63 & & \\
\hline & AA & 0 & 0 & Additive & NA \\
\hline & $\mathrm{CA}+\mathrm{AA}$ & 24 & 63 & Dominant & $0.7(0.3-1.3), p=0.274$ \\
\hline & $\mathrm{CC}+\mathrm{CA}$ & 47 & 104 & Recessive & NA \\
\hline & $\mathrm{CC}+\mathrm{AA}$ & 23 & 41 & Co-dominant & $1.5(0.7-2.9), p=0.274$ \\
\hline & $\mathrm{C}$ & 70 & 145 & & \\
\hline & $\mathrm{A}$ & 24 & 63 & Allele & $0.8(0.4-1.4), p=0.399$ \\
\hline \multirow{8}{*}{$\begin{array}{l}\text { rs2073342 } \\
(+371 \mathrm{C}>\mathrm{G})\end{array}$} & $\mathrm{CC}$ & 6 & 25 & & \\
\hline & CG & 41 & 79 & & \\
\hline & GG & 0 & 0 & Additive & NA \\
\hline & $\mathrm{CG}+\mathrm{GG}$ & 41 & 79 & Dominant & $2.2(0.8-5.7), p=0.118$ \\
\hline & $\mathrm{CC}+\mathrm{CG}$ & 47 & 104 & Recessive & NA \\
\hline & $\mathrm{CC}+\mathrm{GG}$ & 6 & 25 & Co-dominant & $0.5(0.2-1.2), p=0.118$ \\
\hline & $\mathrm{C}$ & 53 & 129 & & \\
\hline & $\mathrm{G}$ & 41 & 79 & Allele & $1.3(0.8-2.1), p=0.354$ \\
\hline \multirow{8}{*}{$\begin{array}{l}\text { rs2233860 } \\
(+499 G>C)\end{array}$} & GG & 40 & 86 & & \\
\hline & GC & 7 & 17 & & \\
\hline & $\mathrm{CC}$ & 0 & 1 & Additive & NA \\
\hline & $\mathrm{GC}+\mathrm{CC}$ & 7 & 18 & Dominant & $0.8(0.3-2.2), p=0.712$ \\
\hline & $\mathrm{GG}+\mathrm{GC}$ & 47 & 103 & Recessive & NA \\
\hline & $\mathrm{GG}+\mathrm{CC}$ & 40 & 87 & Co-dominant & $1.1(0.4-2.9), p=0.821$ \\
\hline & G & 87 & 189 & & \\
\hline & $\mathrm{C}$ & 7 & 19 & Allele & $0.8(0.3-2.0), p=0.629$ \\
\hline
\end{tabular}

$N A$ not applicable due to the presence of 0 value; OR: odds ratio; $95 \% C I$ 95\% confidence interval; $S M$ Severe malaria; $U M$ Uncomplicated malaria

\begin{tabular}{lccllll}
\hline Haplotype & SM (frequency) & UM (frequency) & OR [95\%CI] & Chi $^{2}$ & p value & ${ }^{a} \mathrm{p}$ value \\
\hline A-C-C & $0.0(0.0)$ & $0.18(0.001)$ & - & - & - & - \\
A-C-G & $6.24(0.066)$ & $5.92(0.028)$ & $2.402[0.759-7.603]$ & 2.35 & 0.125 & NS \\
A-G-C & $0.0(0.0)$ & $0.04(0.0)$ & - & - & - & - \\
A-G-G & $17.76(0.189)$ & $56.9(0.274)$ & $0.610[0.335-1.111]$ & 2.64 & 0.104 & NS \\
C-C-C & $7.0(0.074)$ & $16.84(0.081)$ & $0.903[0.361-2.261]$ & 0.05 & 0.827 & NS \\
C-C-G & $39.76(0.423)$ & $106.1(0.510)$ & $0.690[0.422-1.128]$ & 2.2 & 0.138 & NS \\
C-G-C & $0.0(0.0)$ & $1.98(0.01)$ & - & - & - & - \\
C-G-G & $23.24(0.247)$ & $20.12(0.097)$ & $3.031[1.572-5.845]$ & 11.66 & $<0.001$ & $\mathbf{0 . 0 0 8}$ \\
\hline
\end{tabular}

OR odds ratio; $95 \%$ CI 95\% confidence interval; SM Severe malaria; $U M$ Uncomplicated malaria

${ }^{\mathrm{a}} \mathrm{p}$ value $=\mathrm{p}$ value after Bonferroni correction $<0.05$ (in bold) considered to be significant. NS $=$ non-significant between the three polymorphisms was observed in the SM group due to absence of LD between the polymorphisms rs2233859 and rs2073342 $\left(\mathrm{D}^{\prime}=0.57\right)$. The results of the linkage analysis are shown in Fig. S2.

\section{Discussion}

In this first study aiming to decipher the effect of RNASE 3 polymorphisms on SM susceptibility in India, we used the direct DNA sequencing of clinical samples collected using a convenience sampling method from $P f$-positive patients residing in Mangalore, Karnataka, on the Western coast of 
India. We show evidence for the absence of homozygous mutant genotypes for RNASE 3 reported polymorphisms, except for 3' UTR + 499G > C polymorphism, which was only found in one patient. No significant genetic association was found for genotypes and alleles of RNASE 3 polymorphisms with SM in the studied Indian population. This contrasts markedly with two reports on African populations, which showed an association between RNASE 3 polymorphisms and SM susceptibility $[19,20]$.

In Ghana, $+371 \mathrm{C}>\mathrm{G}$ polymorphism was found associated with CM, a neurological type of SM, and $+499 \mathrm{G}>\mathrm{C}$ polymorphism was associated with SM in a Senegalese population $[19,20]$. No such associations were found in the present study. These differing results may be due to several reasons. First, the same polymorphism can have heterogeneous effect in two geographically and genetically distinct populations, despite the endemicity of $P$. falciparum at both sites [25]. Second, the sample size used in the present study was small compared to previous studies [19, 20]. Third, the present study did not include participants with $\mathrm{CM}$ and no past history of malaria, which could have provided higher granularity in our association study. Indeed, the SM patients enrolled in the Senegalese study consisted primarily of CM and severe anemia cases [20]; it is therefore possible that the reported association was driven by a high number of CM patients, which would be in line with the findings from Ghana [19]. It has to be noted that Mangalore city alone contributes about $72 \%$ of total malaria in Karnataka. In the last 5 years, the local district health department instead of the local municipal authority governs the malaria control operation. Following this, active and passive fever surveys through digital surveillance devices are in function throughout the city [31]. Thus, prompt diagnosis and treatment are provided. This may be one of the reasons for not finding CM cases in the present study. However, further studies including large groups of different SM subtypes are needed to test this hypothesis in Indian populations.

We show that in SM patients from India, there is a lack of homozygous mutant genotypes of $+371 \mathrm{C}>\mathrm{G}$ and $+499 \mathrm{G}>\mathrm{C}$ polymorphisms. This absence may indicate that mutant alleles may have a deleterious effect on the Indian population. This could be explained by the presence of heterozygous genotypes in our cohort, which may be to balance the deleterious effect of these mutant alleles, especially for $+371 \mathrm{C}>\mathrm{G}$ missense-polymorphism that has been associated with SM in Ghanaian population [19] and with parasitic-helminth infections in Ugandan population [24]. The $+371 \mathrm{C}>\mathrm{G}$ polymorphism, resulting in an Arg/ Thr substitution, drastically reduces the protein cytotoxicity. The change in cytotoxic activity could be due to the substitution, which creates a potentially new glycosylation site in ECP [24, 32-34]. According to the dbSNP database, a 0.73 minor allele $(\mathrm{G})$ frequency of $+371 \mathrm{C}>\mathrm{G}$ polymorphism has been found in Asia, suggesting that it may increase in Indian population in the future.

Haplotype analysis can provide pivotal evidence on human evolution, and the identification of genetic variants causing specific human traits through linkage disequilibrium [35]. C-G-G haplotype of $-38 \mathrm{C}>\mathrm{A},+371 \mathrm{C}>\mathrm{G}$ and $+499 \mathrm{G}>\mathrm{C}$ polymorphisms were found associated with SM in this study. However, no complete linkage between the three polymorphisms was observed in the SM group. Therefore, in the absence of homozygous genotype for the mutant alleles of $-38 \mathrm{C}>\mathrm{A}$ and $+371 \mathrm{C}>\mathrm{G}$ polymorphisms, any conclusion on the association of C-G-G haplotype with SM would be speculative. Further genetic analyses involving a larger sample size in India are warranted to further explore the possible association we describe here.

SM predominantly affected adults in this study (median age 36 years, interquartile range 26 years), indicating a probable age shift in anti-malarial immunity [36]. This may have resulted from the recent decrease in transmission due to India's largest national malaria control program [37]. Higher bilirubin, AST and ALT levels were found in SM patients, confirming the association between hepatic injury and severe $P f$ infection described in previous studies [38-41]. In addition, low albumin levels, albumin:globulin ratio, and high urea levels were noted in SM patients compared to UM, confirming the presence of liver and kidney injuries (Table 2). Parasitemia was also found significantly increased in SM patients. However, peripheral parasitemia may not be a true indicator of disease severity due to the sequestration of parasitized erythrocytes in the microvasculature of vital organs [42].

This study has a few limitations. In the era of next-generation sequencing and genome wide association studies, we performed a case-control study to assess the role of RNASE 3 polymorphisms in SM susceptibility in an Indian population using Sanger DNA sequencing. This option was chosen as case-control studies using Sanger sequencing assays are less time consuming, cost-effective, reliable, and can be useful for recognizing associating factors of disease outbreaks, as well as current cases, and allow the assessment of multiple risk factors at once [43]. Another limitation was the lack of CM patients included in the study, which may explain the discrepancies between our findings and the ones reported in Ghana and Senegal. Lastly, ECP levels were not assessed in plasma samples collected from study participants due to limited funding.

In conclusion, we tested the hypothesis if RNASE 3 polymorphisms have a role in determining the SM susceptibility in an Indian population, and demonstrated that the homozygous mutant genotype of RNASE 3 polymorphisms ( $+371 \mathrm{C}>\mathrm{G}$ and $+499 \mathrm{G}>\mathrm{C}$ ), which were shown to be associated with CM and SM in the population of Ghana and Senegal, respectively, were absent in our cohort of SM patients. 
However, C-G-G haplotype $(-38 \mathrm{C}>\mathrm{A},+371 \mathrm{C}>\mathrm{G}$ and $+499 \mathrm{G}>\mathrm{C}$ polymorphisms) frequency was significantly higher in SM patients compared to UM, suggesting its association with an increased risk of SM, and further confirming a role of RNASE 3 gene in SM.

Acknowledgements We thank all study participants as well as physicians, technician, nurses from Wenlock District Government Hospital, Mangalore, Karnataka, India, and everyone who supported this study directly or indirectly. We thank the Director, National Institute of Malaria Research, New Delhi, for the opportunity to complete the research work. We also thank Dr. Rajeshwari Devi (District Surgeon and Medical Superintendent, Wenlock District Government Hospital, Mangalore) and Dr. K. Chakrapani (Associate Dean and Head of Medicine department) Kasturba Medical College (Manipal University), Mangalore, Karnataka, India, for their support on this study. We also acknowledge Indian Council of Medical Research, New Delhi, for funding. SCW is supported by a grant from the UK Medical Research Council, award number MR/S009450/1. Authors take this opportunity to applaud and thank health care workers all around the world for their hard work in the COVID-19 crisis.

Author contributions BM participated in fieldwork, collected clinical and epidemiological data, laboratory analyses, and together with HG wrote the first draft of this manuscript. HG also participated in data curation, sequencing and statistical analyses as well as in results interpretation. SCW and AKRA participated in data interpretation and critically reviewing this article. SKG participated in the study design, supervision, generate the resources, manuscript review, project administration and coordinated all the stages of the project. All authors read and approved the final manuscript.

Data availability Anonymized data is available on request.

\section{Compliance with ethical standards}

Conflict of interest The authors declare that they have no conflict of interest.

\section{References}

1. World Health Organization (2019) World Malaria Report 2019. 09/12/2019]; Available from https://www.who.int/news-room/ feature-stories/detail/world-malaria-report-2019

2. Wassmer SC, Taylor TE, Rathod PK, Mishra SK, Mohanty S, Arevalo-Herrera M, Duraisingh MT, Smith JD (2015) Investigating the pathogenesis of severe malaria: a multidisciplinary and cross-geographical approach. Am J Trop Med Hyg 93(3 Suppl):42-56. https://doi.org/10.4269/ajtmh.14-0841

3. Miller LH, Baruch DI, Marsh K, Doumbo OK (2002) The pathogenic basis of malaria. Nature 415(6872):673-679

4. Dondorp AM (2008) Clinical significance of sequestration in adults with severe malaria. Transfus Clin Biol 15(1-2):56-57. https://doi.org/10.1016/j.tracli.2008.04.013

5. Rowe JA, Claessens A, Corrigan RA, Arman M (2009) Adhesion of Plasmodium falciparum-infected erythrocytes to human cells: molecular mechanisms and therapeutic implications. Expert Rev Mol Med 11:e16. https://doi.org/10.1017/S1462399409001082

6. Turner L, Lavstsen T, Berger SS, Wang CW, Petersen JE, Avril M, Brazier AJ, Freeth J, Jespersen JS, Nielsen MA, Magistrado P, Lusingu J, Smith JD, Higgins MK, Theander TG (2013) Severe malaria is associated with parasite binding to endothelial protein C receptor. Nature 498(7455):502-505. https://doi.org/10.1038/ nature 12216

7. Lavstsen T, Turner L, Saguti F, Magistrado P, Rask TS, Jespersen JS, Wang CW, Berger SS, Baraka V, Marquard AM, SeguinOrlando A, Willerslev E, Gilbert MT, Lusingu J, Theander TG (2012) Plasmodium falciparum erythrocyte membrane protein 1 domain cassettes 8 and 13 are associated with severe malaria in children. Proc Natl Acad Sci USA 109(26):E1791-E1800. https ://doi.org/10.1073/pnas.1120455109

8. Magallón-Tejada A, Machevo S, Cisteró P, Lavstsen T, Aide P, Rubio M, Jiménez A, Turner L, Valmaseda A, Gupta H, De Las SB, Mandomando I, Wang CW, Petersen JE, Muñoz J, Gascón J, Macete E, Alonso PL, Chitnis CE, Bassat Q, Mayor A (2016) Cytoadhesion to gC1qR through Plasmodium falciparum Erythrocyte Membrane Protein 1 in severe malaria. PLoS Pathog 12(11):e1006011. https://doi.org/10.1371/journal.ppat.1006011

9. Sinha S, Qidwai T, Kanchan K, Anand P, Jha GN, Pati SS, Mohanty S, Mishra SK, Tyagi PK, Sharma SK, Indian Genome Variation Consortium, Venkatesh V, Habib S (2008) Variations in host genes encoding adhesion molecules and susceptibility to falciparum malaria in India. Malar J. 7:250. https://doi. org/10.1186/1475-2875-7-250

10. Olaniyan SA, Amodu OK, Bakare AA, Troye-Blomberg M, Omotade OO, Rockett KA, MalariaGEN Consortium (2016) Tumour necrosis factor alpha promoter polymorphism, TNF-238 is associated with severe clinical outcome of falciparum malaria in Ibadan southwest Nigeria. Acta Trop. 161:62-67. https://doi. org/10.1016/j.actatropica.2016.05.006

11. Nasr A, Allam G, Hamid O, Al-Ghamdi A (2014) IFN-gamma and TNF associated with severe falciparum malaria infection in Saudi pregnant women. Malar J. 13:314. https://doi. org/10.1186/1475-2875-13-314

12. Gyan B, Goka B, Cvetkovic JT, Perlmann H, Lefvert AK, Akanmori B, Troye-Blomberg M (2002) Polymorphisms in interleukin1 beta and interleukin-1 receptor antagonist genes and malaria in Ghanaian children. Scand J Immunol 56(6):619-622

13. Ouma C, Davenport GC, Awandare GA, Keller CC, Were T, Otieno MF, Vulule JM, Martinson J, Ong'echa JM, Ferrell RE, Perkins DJ (2008) Polymorphic variability in the interleukin (IL)1 beta promoter conditions susceptibility to severe malarial anemia and functional changes in IL-1beta production. J Infect Dis 198(8):1219-1226. https://doi.org/10.1086/592055

14. Panda AK, Panda M, Tripathy R, Pattanaik SS, Ravindran B, Das BK (2012) Complement receptor 1 variants confer protection from severe malaria in Odisha, India. PLoS ONE 7(11):e49420. https ://doi.org/10.1371/journal.pone.0049420

15. Gupta H, Chaudhari S, Rai A, Bhat S, Sahu PK, Hande MH, D'Souza SC, Shashikiran U, Satyamoorthy K (2017) Genetic and epigenetic changes in host ABCB1 influences malaria susceptibility to Plasmodium falciparum. PLoS ONE 12(4):e0175702. https ://doi.org/10.1371/journal.pone.0175702

16. Gupta H, Jain A, Saadi AV, Vasudevan TG, Hande MH, D'Souza SC, Ghosh SK, Umakanth S, Satyamoorthy K (2015) Categorical complexities of Plasmodium falciparum malaria in individuals is associated with genetic variations in ADORA2A and GRK5 genes. Infect Genet Evol 34:188-199. https://doi.org/10.1016/j. meegid.2015.06.010

17. Venge P, Byström J, Carlson M, Hâkansson L, Karawacjzyk M, Peterson C, Sevéus L, Trulson A (1999) Eosinophil cationic protein (ECP): molecular and biological properties and the use of ECP as a marker of eosinophil activation in disease. Clin Exp Allergy 29(9):1172-1186. https://doi.org/10.104 6/j.1365-2222.1999.00542.x

18. Boix E, Salazar VA, Torrent M, Pulido D, Nogués MV, Moussaoui M (2012) Structural determinants of the eosinophil cationic 
protein antimicrobial activity. Biol Chem 393(8):801-815. https ://doi.org/10.1515/hsz-2012-0160

19. Adu B, Dodoo D, Adukpo S, Gyan BA, Hedley PL, Goka B, Adjei GO, Larsen SO, Christiansen M, Theisen M (2011) Polymorphisms in the RNASE3 gene are associated with susceptibility to cerebral malaria in Ghanaian children. PLoS ONE 6(12):e29465. https://doi.org/10.1371/journal.pone.0029465

20. Diop G, Derbois C, Loucoubar C, Mbengue B, Ndao BN, Thiam F, Thiam A, Ndiaye R, Dieye Y, Olaso R, Deleuze JF, Dieye A (2018) Genetic variants of RNASE3 (ECP) and susceptibility to severe malaria in Senegalese population. Malar J 17(1):61. https ://doi.org/10.1186/s12936-018-2205-9

21. Kurtzhals JA, Reimert CM, Tette E, Dunyo SK, Koram KA, Akanmori BD, Nkrumah FK, Hviid L (1998) Increased eosinophil activity in acute Plasmodium falciparum infection-association with cerebral malaria. Clin Exp Immunol 112(2):303-307

22. Waters LS, Taverne J, Tai PC, Spry CJ, Targett GA, Playfair JH (1987) Killing of Plasmodium falciparum by eosinophil secretory products. Infect Immun 55(4):877-881

23. Jönsson UB, Håkansson LD, Jõgi R, Janson C, Venge P (2010) Associations of ECP (eosinophil cationic protein)-gene polymorphisms to allergy, asthma, smoke habits and lung function in two Estonian and Swedish sub cohorts of the ECRHS II study. BMC Pulm Med 10:36. https://doi.org/10.1186/1471-2466-10-36

24. Eriksson J, Reimert CM, Kabatereine NB, Kazibwe F, Ireri E, Kadzo H, Eltahir HB, Mohamed AO, Vennervald BJ, Venge P (2007) The 434(G>C) polymorphism within the coding sequence of Eosinophil Cationic Protein (ECP) correlates with the natural course of Schistosoma mansoni infection. Int J Parasitol 37(12):1359-1366. https://doi.org/10.1016/j.ijpara.2007.04.001

25. Lin PI, Vance JM, Pericak-Vance MA, Martin ER (2007) No gene is an island: the flip-flop phenomenon. Am J Hum Genet 80(3):531-538

26. World Health Organization (2015) Guidelines for the treatment of malaria. 3rd ed. 2015. 27/11/2019]; Available from https://www. who.int/malaria/publications/atoz/9789241549127/en/

27. Punnath K, Dayanand KK, Chandrashekhar VN, Achur RN, Kakkilaya SB, Ghosh SK, Kumari SN, Gowda DC (2019) Association between inflammatory cytokine levels and anemia during Plasmodium falciparum and Plasmodium vivax infections in Mangaluru: a Southwestern Coastal Region of India. Trop Parasitol 9(2):98-107. https://doi.org/10.4103/tp.TP_66_18

28. Sanger F, Nicklen S, Coulson AR (1977) DNA sequencing with chain-terminating inhibitors. Proc Natl Acad Sci USA 74(12):5463-5467

29. Shi YY, He L (2005) SHEsis, a powerful software platform for analyses of linkage disequilibrium, haplotype construction, and genetic association at polymorphism loci. Cell Res 15(2):97-98

30. Li Z, Zhang Z, He Z, Tang W, Li T, Zeng Z, He L, Shi Y (2009) A partition-ligation-combination-subdivision EM algorithm for haplotype inference with multiallelic markers: update of the SHEsis (http://analysis.bio-x.cn). Cell Res. 19(4):519-523. https://doi. org/10.1038/cr.2009.33
31. Baliga BS, Jain A, Koduvattat N, Kumar BGP, Kumar M, Kumar A, Ghosh SK (2019) Indigenously developed digital handheld Android-based Geographic Information System (GIS)-tagged tablets (TABs) in malaria elimination programme in Mangaluru city, Karnataka, India. Malar J 18(1):444. https://doi.org/10.1186/ s12936-019-3080-8

32. Trulson A, Byström J, Engström A, Larsson R, Venge P (2007) The functional heterogeneity of eosinophil cationic protein is determined by a gene polymorphism and post-translational modifications. Clin Exp Allergy 37(2):208-218. https://doi.org/10.111 1/j.1365-2222.2007.02644.x

33. Eriksson J, Woschnagg C, Fernvik E, Venge P (2007) A SELDITOF MS study of the genetic and post-translational molecular heterogeneity of eosinophil cationic protein. J Leukoc Biol 82(6):1491-1500. https://doi.org/10.1189/jlb.0507272

34. Salazar VA, Rubin J, Moussaoui M, Pulido D, Nogués MV, Venge P, Boix E (2014) Protein post-translational modification in host defense: the antimicrobial mechanism of action of human eosinophil cationic protein native forms. FEBS J 281(24):5432-5446. https://doi.org/10.1111/febs.13082

35. Liu N, Zhang K, Zhao H (2008) Haplotype-association analysis. Adv Genet 60:335-405. https://doi.org/10.1016/S0065 -2660(07)00414-2

36. Fowkes FJ, Boeuf P, Beeson JG (2016) Immunity to malaria in an era of declining malaria transmission. Parasitology 143(2):139 153. https://doi.org/10.1017/S0031182015001249

37. Ghosh SK, Rahi M (2019) Malaria elimination in India-The way forward. J Vector Borne Dis 56(1):32-40. https://doi. org/10.4103/0972-9062.257771

38. Anand AC, Ramji C, Narula AS, Singh W (1992) Malarial hepatitis: a heterogeneous syndrome? Natl Med J India 5(2):59-62

39. Chawla LS, Sidhu G, Sabharwal BD, Bhatia KL, Sood A (1989) Jaundice in Plasmodium falciparum. J Assoc Physicians India 37(6):390-391

40. Kochar DK, Agarwal P, Kochar SK, Jain R, Rawat N, Pokharna RK, Kachhawa S, Srivastava T (2003) Hepatocyte dysfunction and hepatic encephalopathy in Plasmodium falciparum malaria. QJM 96(7):505-512

41. Kochar DK, Singh P, Agarwal P, Kochar SK, Pokharna R, Sareen PK (2003) Malarial hepatitis. J Assoc Physicians India 51:1069-1072

42. Dondorp AM, Desakorn V, Pongtavornpinyo W, Sahassananda D, Silamut K, Chotivanich K, Newton PN, Pitisuttithum P, Smithyman AM, White NJ, Day NP (2005) Estimation of the total parasite biomass in acute falciparum malaria from plasma PfHRP2. PLoS Med 2(8):e204

43. Tenny S, Hoffman MR (2020) Case Control Studies. StatPearls [Internet]. StatPearls Publishing, Treasure Island

Publisher's Note Springer Nature remains neutral with regard to jurisdictional claims in published maps and institutional affiliations. 